\title{
USO DO SOLO NA ZONA RIPÁRIA DE BACIAS AGRÍCOLAS DE PEQUENO A MÉDIO PORTE ${ }^{1}$
}

\author{
Adilson Pinheiro², Jader Bertoldi ${ }^{2}$, Alexander Christian Vibrans², Vander Kaufmann² e Michel Deshayes ${ }^{3}$
}

\begin{abstract}
RESUMO - As zonas ripárias situam-se às margens dos sistemas de drenagens de águas superficiais, afetando processos hidrológicos. O Código Florestal Brasileiro estabelece um afastamento mínimo ao longo dos cursos de águas, considerado como área de preservação permanente. Este trabalho objetivou determinar a distribuição do uso do solo em bacias agrícolas com várias dimensões para diferentes afastamentos em relação ao sistema de drenagem de águas superficiais. A metodologia utilizada compreendeu o uso de imagens do satélite SPOT-5, para classificação do uso de solo em seis bacias com áreas variando de 14 a $600 \mathrm{~km}^{2}$. A precisão da classificação foi determinada pela acuracidade e o nível de acerto, determinado pelo coeficiente Kappa. A partir do sistema de drenagem foram traçadas linhas paralelas aos cursos de águas, denominados buffers, com afastamento das margens de 20, 30, 50, 100 e 200 m. Em cada buffer foi determinada a distribuição da ocupação do uso do solo. Os valores obtidos com a classificação indicaram acerto com coeficiente Kappa médio de 0,96. Os temas classificados em todas as imagens apresentaram boa acuracidade, com valores maiores que $96 \%$. Os resultados apontaram que o uso da terra predominante em todas as bacias é a mata nativa com valores médios de 46,8\%, seguida de culturas agrícolas com $24,7 \%$ e pastagens com $21,7 \%$. As áreas de matas nativas apresentavam tendência de redução à medida que se afastavam dos cursos de água, enquanto os reflorestamentos tendiam a aumentar o percentual da área ocupada com o afastamento das margens dos rios.
\end{abstract}

Palavras-chave: Zona ripária, Uso e ocupação do solo e Bacia agrícola.

\section{LAND USE OF RIPARIAN ZONES IN SMALL AND MEDIUM SIZED RURAL WATERSHEDS}

\begin{abstract}
Riparian zones are situated along the river margins, affecting ecological processes at the interface between terrestrial and aquatic ecosystems within watersheds. The Brazilian forest code established minimum distance buffers alongside river called permanent preservation areas. This work focuses on the distribution of land use types in different distances along superficial streams in watersheds of different sizes. SPOT-5 images were used to classify land use in six watersheds with areas between 14 and $600 \mathrm{~km}^{2}$. Land use was quantified within buffers at 20, 30, 50, 100 and $200 \mathrm{~m}$ width along the streams. Medium classification accuracy achieved a Kappa coefficient of 0.96. Dominant land use of riparian zones is natural forest cover (46.8\% of total surface), followed by crop cultures (24.7\%) and pastures (21.7\%). Natural forest cover decreases with the increase of distance from the river margins, while afforestation cover increases.
\end{abstract}

Keywords: Riparian zone, Land use and Rural watershed.

\footnotetext{
${ }^{1}$ Recebido em 19.11.2009 e aceito para publicação em 31.10.2011.

${ }^{2}$ Fundação Universidade Regional de Blumenau, FURB, Brasil. E-mail: <pinheiro@furb.br>.

${ }^{3}$ UMR TETIS - Territoires, Environnement, Télédétection et Information Spatiale (Cemagref /CIRAD/ENGREF) 500 rue Jean-François Breton, 34093, Montpellier Cedex 5, França. E-mail: <deshayes@teledetection.fr>.
} 


\section{INTRODUÇÃO}

As zonas ripárias têm por funções contribuir para a retenção de sedimentos e de espécies químicas nos corpos de água e interceptar e absorver a luz do sol e a água da chuva, o que favorece a recarga dos lençóis subterrâneos que abastecem as nascentes, além de funcionarem como reguladoras climáticas, minimizando os extremos de temperaturas, funcionando como zonatampão, entre outras (PRIMAK; RODRIGUES, 2001). A zona- tampão promove maior infiltração de água e retém os sedimentos vindos da erosão do solo ou da erosão eólica (NORDSTROM; HOTTA, 2004). Quando mantida adequadamente, pode remover até 97\% dos sedimentos do solo antes da sua entrada no escoamento fluvial (LEE et al., 2003; LOWRANCE et al., 2002, MAYER et al., 2005). Além disso, pode ser importante na proteção dos cursos de águas contra a erosão e o escorregamento (HOLANDA et al., 2005).

Estudos têm evidenciado a eficácia das zonas ripárias na redução das concentrações de nitratos, fósforo e uma série de compostos de pesticidas em bacias agrícolas. O nitrogênio é absorvido pelas plantas nas zonas ripárias. A concentração de nitrato-N pode ser reduzida entre 40 e 94\% em um tampão ou zonas úmidas antes de entrar no corpo de água, apesar de taxas de remoção mais perto de $50 \%$ serem mais aceitas em medições efetuadas atualmente (KOVACIC et al., 2000; LOWRANCE et al., 2002; STONE et al., 2004).

No Brasil, as zonas ripárias são legalmente protegidas como áreas de preservação permanente (APP), de acordo com o Código Florestal Brasileiro (Lei Federal $n^{\circ} 4771$, de 1965). Ele estabelece um afastamento mínimo ao longo dos cursos de águas. Essa “distância” não é muito reconhecida, ou até mesmo não levada em conta, e passou a não existir em muitas dessas áreas, visto que vários fatores influenciam no seu desempenho. A legislação estabelece valores fixos de larguras das zonas ripárias em função da magnitude do corpo de água. No entanto, fatores físicos, químicos e biológicos controlam o funcionamento desejado dessas faixas. Esses fatores não têm sido estabelecidos para as condições brasileiras, principalmente nos diferentes tipos de solo e condições climáticas.

Este trabalho teve por objetivo determinar a tipologia de ocupação do uso do solo nas áreas laterais aos cursos de água, em bacias de diferentes magnitudes situadas na parte superior da bacia do rio Itajaí, a qual está inserida na vertente atlântica do Estado de Santa Catarina. Duas motivações foram apresentadas para a realização deste trabalho. De acordo com Vibrans (2003), a bacia do rio Itajaí apresentava em 2000 cerca de $67 \%$ de cobertura florestal natural, entre florestas e formações de sucessão secundária, e, de acordo com a EPAGRI (2001), há predominância de pequenas e médias propriedades, pois $91,1 \%$ possuem menos de 50 ha.

Para a realização deste trabalho foram selecionadas seis bacias hidrográficas, localizadas na parte superior da bacia do rio Itajaí (Figura 1). Nessas bacias foram implantados programas de monitoramento da qualidade das águas, por diferentes projetos de pesquisa ou de extensão rural. Além disso, elas estão contidas nas imagens de satélite SPOT-5, com resolução espacial de 2,5 e 10 m, em quatro bandas. As áreas de drenagem das bacias hidrográficas variam entre 14 e $600 \mathrm{~km}^{2}$ (Tabela 1).

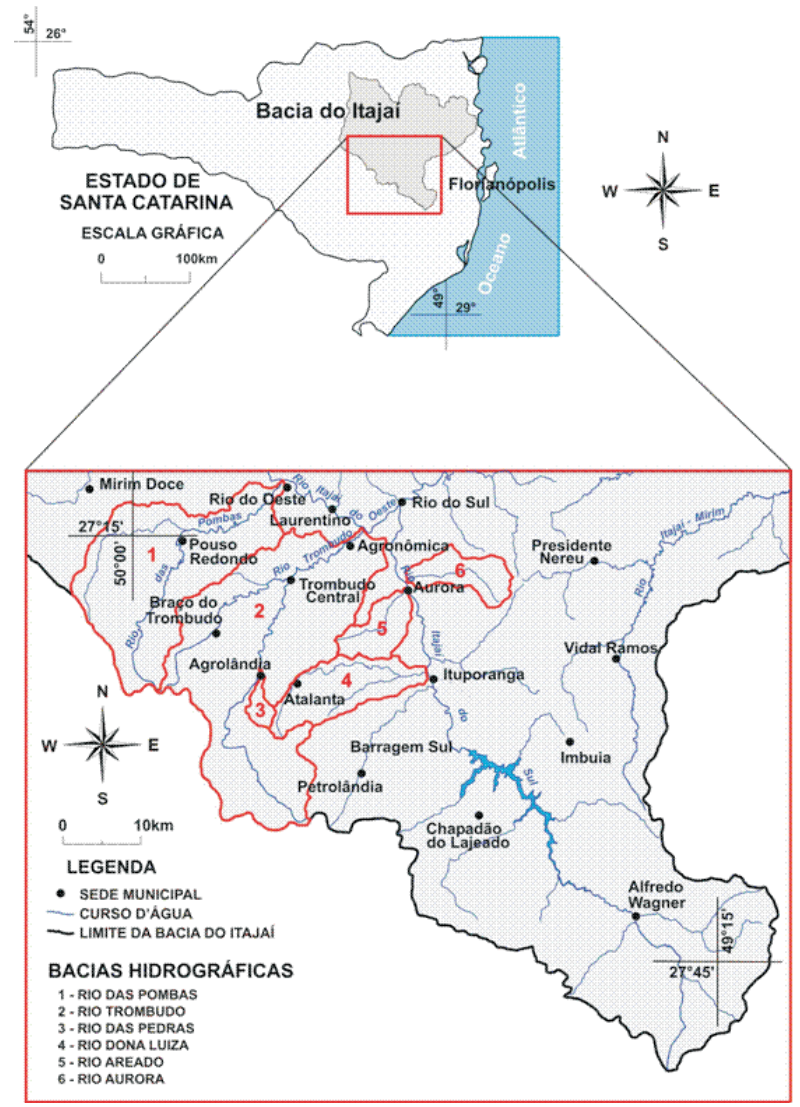

Figura 1 - Localização das bacias estudadas.

Figure 1 - Localization of analyzed watershed. 
Tabela 1 - Áreas de drenagem das bacias hidrográficas. Table 1 - Watershed areas.

\begin{tabular}{lc}
\hline Bacia Hidrográfica & Área de drenagem $\left(\mathrm{km}^{2}\right)$ \\
\hline Ribeirão das Pedras & 14,19 \\
Ribeirão Dona Luiza & 35,49 \\
Ribeirão Areado & 51,04 \\
Ribeirão Aurora & 53,85 \\
Rio das Pombas & 362,05 \\
Rio Trombudo & 597,03 \\
\hline
\end{tabular}

A região apresenta clima subtropical úmido com verões quentes. Em alguns municípios ocorrem áreas com altitude elevada, caracterizando a transição para o clima temperado úmido. A temperatura média anual é de $20^{\circ} \mathrm{C}$, ocorrendo em média quatro geadas por ano, normalmente nos meses de junho e julho. A precipitação anual varia entre 1.600 e $1.800 \mathrm{~mm}$, sendo as chuvas mais intensas nos meses de verão. A insolação anual situa-se ao redor de 1.745 h (EPAGRI, 2001).

\section{MATERIAL E MÉTODOS}

A confecção e interpretação dos mapas de uso da terra, bem como a determinação das áreas de cada cultura e a interpretação dos dados de cada bacia, foram realizadas utilizando-se os softwares ENVI/RSI 4.3 e ArcGIS/ESRI 9.1, que trouxeram interpretações de maior confiabilidade e segurança.

Primeiramente, de posse do mapa hidrográfico e de curvas de nível de áreas de abrangência (base: mapeamento sistemático brasileiro na escala 1:50.000), foram determinados os divisores de águas das bacias estudadas. Em seguida foram feitos os recortes das imagens que seriam usadas para a classificação da área. Utilizaram-se imagens multiespectrais do satélite SPOT-5, sensor HRS, de órbita/pontos 712/404 de 22/05/2005, $712 / 405$ de 22/05/2005 e 713/404 de 30/04/2006, reamostradas para $5 \mathrm{~m}$ de resolução espacial a partir da banda pancromática.

No processo de interpretação visual das imagens, foram utilizadas as bandas da composição R3, G2 e B1, sendo a imagem processada com o uso do software ENVI 4.3.

A partir da observação dessas imagens, foram destacados os elementos básicos que possibilitaram a interpretação e classificação da imagem, como cor, textura, tamanho e forma. Nos recortes realizados anteriormente, foram determinadas e identificadas “áreas de treinamento” com verdade terrestre conhecida. Essas áreas foram divididas em classes temáticas, distribuídas da seguinte forma: mata nativa, reflorestamento, pastagem, culturas, sombra e água.

Posteriormente, as áreas foram demarcadas, criando-se polígonos na imagem chamados de "regiões de interesse" (ROI - regions of interest). Os pixels demarcados por esses polígonos foram submetidos a análises estatísticas, extraindo-se, assim, as médias e os desvios-padrão dos seus atributos espectrais. Com base nas áreas de treinamento escolhidas, foi realizada a classificação supervisionada das imagens, utilizando-se o algoritmo da Máxima Verossimilhança. A confiabilidade dessa classificação fica condicionada a alguns fatores, podendo-se destacar a suposição da distribuição normal da variabilidade espectral dos pixels nas classes temáticas e a adequada escolha das áreas de treinamento, que devem ser representativas e compostas por pixels com características homogêneas, distribuídas em classes de boa separabilidade espectral.

A aferição da classificação foi baseada na matriz de confusão, que pode considerar-se como a quantificação das diferenças encontradas entre a verdade observada em campo e a imagem classificada. Várias classificações foram feitas para que as taxas de comissão e omissão das respectivas classes pudessem ser minimizadas, buscando-se, assim, a melhor classificação de cada tema apresentado. Após a realização de todas as etapas da classificação, foram gerados mapas de uso da terra, utilizados para quantificar os diferentes tipos de cobertura vegetal do local. Esses mapas foram importados do ambiente ArcGIS, para a criação de buffers com as distâncias de 20, 30, 50, 100 e 200 m, consecutivamente, a partir das margens de cada curso d’água. Considera-se buffer a área que envolve determinado local, podendo este ser representado por linhas ou polígonos. Essa função é extremamente útil em análise de proximidades, por exemplo no cálculo de áreas de proteção, como foi utilizado neste trabalho. Esses buffers foram criados seguindo-se o curso dos rios, e suas distâncias foram determinadas a partir da margem de cada um deles.

\section{RESULTADOS E DISCUSSÃO}

O coeficiente Kappa, utilizado como indicador na análise do desempenho do processo de classificação das imagens de satélite SPOT-5, apresentou valor médio de 0,96 . Os temas classificados em todas as imagens 
mostraram boa acuracidade, com valores maiores que $96 \%$, indicando que grande parte das áreas de treinamento foram corretamente classificadas.

As distribuições espaciais das classificações realizadas em cada bacia são apresentadas na Figura 2, que permite observar que os diferentes usos e ocupações do solo são, em geral, bem distribuídos ao longo das bacias. As distribuições dos usos e ocupações são apresentadas na Tabela 2, na qual as principais foram: matas nativas (consideradas florestas na maioria dos casos, secundárias e em diversos estágios de regeneração), pastagens, culturas e reflorestamentos. Outros tipos de usos e ocupações foram identificados, porém não significativos.

As matas nativas (Tabela 2) ocupavam 46,8 $\pm 12,8 \%$ das superfícies das bacias, sendo o maior valor encontrado na bacia do ribeirão Aurora $(71,4 \%)$ e, o menor, na bacia do ribeirão das Pedras $(35,4 \%)$.
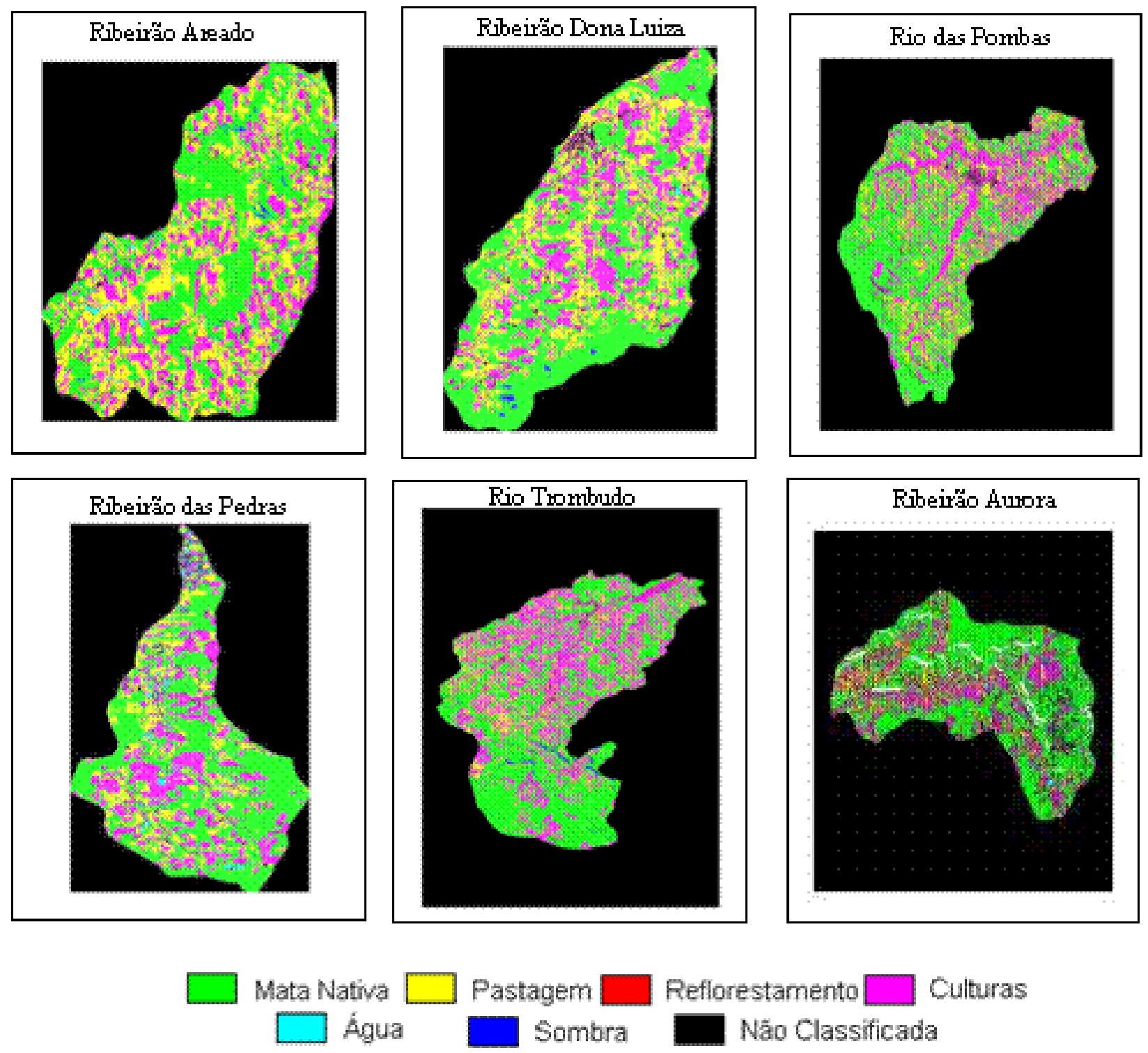

Reflorestamento

\section{Culturas}

Figura 2 - Distribuição dos usos e ocupações do solo nas bacias

Figure 2 - Land use distribution within watersheds.

Revista Árvore, Viçosa-MG, v.35, n.6, p.1245-1251, 2011 
As culturas ocupavam $24,7 \pm 9,8 \%$ e as pastagens, $21,7 \pm 7,0 \%$. No caso dos reflorestamentos, as porcentagens classificadas foram relativamente baixas, tendo sido da ordem de $0,6 \pm 1,0 \%$. A maior porcentagem de reflorestamento ocorreu na bacia do ribeirão das Pedras. As bacias dos ribeirões Aurora e Dona Luiza não apresentaram a ocorrência de reflorestamentos.

Esses valores são diferentes daqueles obtidos no estudo de classificação de uso da terra na bacia do Itajaí, realizado por Vibrans (2003), com imagens
Landsat TM-7 do ano 2000. Esse autor determinou que matas nativas ocupavam $67,8 \%$ da bacia e a agricultura/ pastagem, 24,3\%. Nas bacias classificadas, as matas nativas ocupavam área cerca de 44,7\% menor do que a que ocorria em toda a bacia do Itajaí. Assim, dois aspectos podem ser considerados: a região apresenta o maior desenvolvimento da atividade agrícola da bacia e pode ter havido redução da mata nativa no período de 2000 a 2005. Entretanto, ao comparar o uso e ocupação da sub-bacia do rio Itajaí do Sul, determinado pelo

Tabela 2 - Uso e ocupação do solo nas bacias e nos buffers (\%).

Table 2 - Land use within basins and riverside buffers (\%).

\begin{tabular}{|c|c|c|c|c|c|c|}
\hline \multirow[t]{2}{*}{ Uso e Ocupação do solo } & \multirow[t]{2}{*}{ Total Bacia } & \multicolumn{5}{|c|}{ Buffer $(\mathrm{m})$} \\
\hline & & $0-20$ & $0-30$ & $0-50$ & $0-100$ & $0-200$ \\
\hline \multicolumn{7}{|c|}{ Bacia do Ribeirão Aurora } \\
\hline Mata Nativa & 71,4 & 72,2 & 66,0 & 66,0 & 61,6 & 60,8 \\
\hline Pastagem & 11,5 & 8,8 & 8,5 & 9,0 & 9,6 & 9,9 \\
\hline Culturas & 7,3 & 7,0 & 8,5 & 8,5 & 9,6 & 9,8 \\
\hline Reflorestamento & 0,0 & 0,0 & 0,0 & 0,0 & 0,0 & 0,0 \\
\hline Outros usos & 9,8 & 12,0 & 17,0 & 16,5 & 19,2 & 19,5 \\
\hline \multicolumn{7}{|c|}{ Bacia do Ribeirão Areado } \\
\hline Mata Nativa & 39,4 & 46,9 & 46,2 & 45,1 & 43,7 & 40,7 \\
\hline Pastagem & 30,9 & 31,6 & 31,6 & 31,1 & 30,4 & 30,9 \\
\hline Culturas & 23,3 & 19,5 & 20,0 & 20,8 & 21,8 & 23,0 \\
\hline Reflorestamento & 0,2 & 0,04 & 0,05 & 0,05 & 0,08 & 0,11 \\
\hline Outros usos & 6,2 & 2,0 & 2,2 & 3,0 & 4,0 & 5,2 \\
\hline \multicolumn{7}{|c|}{ Bacia do Ribeirão das Pedras } \\
\hline Mata Nativa & 35,3 & 38,8 & 39,5 & 39,3 & 37,0 & 36,0 \\
\hline Pastagem & 26,6 & 26,3 & 25,9 & 26,3 & 27,2 & 26,8 \\
\hline Culturas & 30,2 & 32,3 & 31,8 & 31,0 & 31,1 & 30,7 \\
\hline Reflorestamento & 2,6 & 0,9 & 0,9 & 1,0 & 1,5 & 2,1 \\
\hline Outros usos & 5,3 & 1,7 & 1,8 & 2,4 & 3,3 & 4,4 \\
\hline \multicolumn{7}{|c|}{ Bacia do Ribeirão Dona Luiza } \\
\hline Mata Nativa & 44,6 & 53,3 & 52,0 & 52,5 & 50,1 & 46,8 \\
\hline Pastagem & 24,5 & 23,5 & 23,6 & 23,2 & 23,1 & 24,0 \\
\hline Culturas & 22,4 & 19,6 & 20,5 & 20,0 & 21,3 & 22,2 \\
\hline Reflorestamento & 0,0 & 0,0 & 0,0 & 0,0 & 0,0 & 0,0 \\
\hline Outros usos & 8,5 & 3,6 & 3,9 & 4,3 & 5,5 & 7,0 \\
\hline \multicolumn{7}{|c|}{ Bacia do rio Trombudo } \\
\hline Mata Nativa & 47,8 & 44,9 & 44,9 & 45,1 & 45,5 & 46,2 \\
\hline Pastagem & 17,3 & 15,8 & 15,9 & 15,9 & 16,0 & 16,1 \\
\hline Culturas & 29,3 & 28,6 & 28,6 & 28,6 & 28,8 & 29,0 \\
\hline Reflorestamento & 1,0 & 0,9 & 0,9 & 0,9 & 0,9 & 0,9 \\
\hline Outros usos & 4,6 & 9,8 & 9,7 & 9,5 & 8,7 & 7,8 \\
\hline \multicolumn{7}{|c|}{ Bacia do rio das Pombas } \\
\hline Mata Nativa & 42,5 & 40,8 & 40,4 & 40,3 & 40,4 & 40,7 \\
\hline Pastagem & 19,2 & 18,4 & 17,3 & 16,9 & 17,1 & 17,7 \\
\hline Culturas & 35,6 & 32,4 & 33,3 & 33,5 & 33,3 & 32,5 \\
\hline Reflorestamento & 0,000 & 0,01 & 0,01 & 0,01 & 0,01 & 0,02 \\
\hline Outros usos & 2,7 & 8,4 & 9,0 & 9,2 & 9,2 & 9,0 \\
\hline
\end{tabular}


mesmo estudo, verificou-se que a mata nativa ainda era inferior à que havia em 2000 (16,6\%). Isso indica a possibilidade de ter havido diminuição da mata nativa nos últimos anos. No entanto, esses valores não podem ser considerados de forma absoluta, pois eram apenas áreas amostrais, que não representavam a totalidade da sub-bacia considerada.

A evolução dos usos e ocupação dos solos (Tabela 2) entre os buffers não são uniformes, pois há aumento ou redução de determinado uso e ocupação do solo entre buffers sucessivos. Comparando os usos e ocupações das bacias com aquelas do buffer de $30 \mathrm{~m}$, que corresponde, no geral, à área de preservação permanente estabelecida pelo Código Florestal, obtém-se uma diferença de cerca de 30\%. No entanto, se a comparação for realizada com o buffer de $200 \mathrm{~m}$, constata-se que a diferença é de cerca de 22\%. Todavia, é possível constatar que nas bacias analisadas grande parte das áreas de preservação permanente $(0-30 \mathrm{~m})$ era cultivada, apresentando apenas entre 39,5 e 66,0\% da cobertura florestal natural exigida pelo Código Florestal. A bacia do ribeirão Aurora apresentava situação melhor, provavelmente devido à redução da atividade agrícola nessa bacia (7,3\%). Resultado similar foi obtido por Ferreira e Dias (2004) na bacia do ribeirão São Bartolomeu, no Estado de Minas Gerais.

A distribuição do uso e ocupação do solo médio entre os buffers é apresentada na Figura 3, em que se observa que na faixa de $0-20 \mathrm{~m}$ a mata nativa ocupava, em média, 42,83 \pm 21,36\%. Esse valor é inferior ao da área total, indicando que próximo aos cursos de água

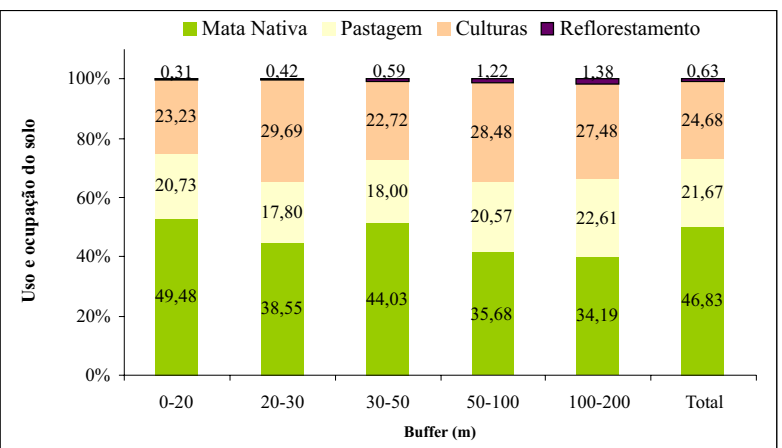

Figura 3 - Distribuição média do uso e ocupação do solo nas seis bacias estudadas.

Figure 3-Medium distribution of land use types in six analyzed watersheds. há uma porcentagem menor de matas nativas. Isso pode ser devido à existência de outros usos, como a rizicultura, que ocorria em algumas bacias, a exemplo daquela do rio Trombudo e do rio das Pombas. As áreas de culturas, de pastagens e de reflorestamento também eram menores nessa faixa do que em toda a bacia.

\section{CONCLUSÕES}

Vários fatores induzem a ocupação das zonas ripárias pela agricultura e pelas pastagens. Foi geralmente nessas áreas que a agricultura se estabeleceu, historicamente devido ao fato de o solo possuir maior fertilidade e ser arável e drenado, além de apresentar baixa declividade. À medida que se afastava do curso, notava-se maior declividade.

As áreas ocupadas por reflorestamentos eram maiores à medida que se afastavam dos cursos de água. Próximo a esses cursos, eles representavam 0,31 \pm 0,47\%, enquanto na faixa de $100-200 \mathrm{~m}$ o porcentual era de $1,38 \pm 2,71 \%$. Em contrapartida, as matas nativas apresentavam tendência de decréscimo à medida que se afastavam dos cursos de água, com uma taxa bastante significativa. Na faixa de 0-20 m, matas nativas ocupavam $49,48 \pm 12,21 \%$ e na faixa de $100-200 \mathrm{~m}$, o percentual era de $34,14 \pm 18,57 \%$. Com relação às pastagens, observou-se que ocorria decréscimo da faixa de 0-20 m para a de 20-30 m e, em seguida, havia um percentual de área ocupada. Entre 100 e 200 m, a área com pastagens era de 22,61 $\pm 9,65 \%$. Os percentuais de áreas ocupadas pelas culturas eram variáveis à medida que se afastam dos cursos de água.

Um importante efeito do aumento de pastagens próximo aos cursos de água era o incremento do tempo de resposta de uma bacia aos eventos de chuvas intensas. Teixeira (2008) e Anjos et al. (1994) mostraram que a capacidade de infiltração de áreas de pastagens é menor do que nas áreas cultivadas ou em matas nativas. Em consequência, tem-se que a geração de escoamentos superficiais hortonianos deve ser mais elevada em áreas de pastagens do que em áreas com culturas ou com matas nativas. Esses escoamentos são responsáveis pela geração de ondas de cheias, desagregação e transporte de partículas do solo e de agroquímicos presentes na camada superficial do solo. No entanto, a existência de cerca de duas vezes mais matas nativas do que pastagem nas faixas próximas dos cursos de água pode minimizar esse efeito negativo. Isso deve

Revista Árvore, Viçosa-MG, v.35, n.6, p.1245-1251, 2011 
ser demonstrado com estudos específicos relacionados aos processos hidrológicos de geração dos escoamentos em zonas ripárias (OCAMPO et al., 2006).

A análise dos usos e ocupações do solo nas zonas ripárias determinados nas bacias hidrográficas de pequeno e grande portes situadas na parte superior da bacia do rio Itajaí indicou que as áreas de preservação permanente ao longo dos cursos de água eram intensivamente usadas pela agricultura e mostravam cobertura florestal muito deficitária, necessitando de ações urgentes de recuperação. As áreas de matas nativas apresentavam tendência de redução à medida que se afastavam dos cursos de água. Na faixa de 0-20 m, o percentual de área de pastagem era elevado, podendo aumentar os escoamentos superficiais hortonianos. Os reflorestamentos evidenciavam tendência de crescimento da porcentagem da área ocupada com o afastamento dos cursos de água.

\section{AGRADECIMENTOS}

À SPOT IMAGES (processo ISIS 0611-944), pelo fornecimento das imagens do satélite SPOT-5 para a realização desta pesquisa.

\section{REFERÊNCIAS}

ANJOS, J. T. et al. Propriedades físicas em solos sob diferentes sistemas de uso e manejo.

Revista Brasileira de Ciências do Solo, v.18, n.1, p.139-145, 1994.

\section{EMPRESADE PESQUISAAGROPECUÁRIAE EXTENSÃO RURAL DE SANTA CATARINA - EPAGRI. Relatório da Gerência Regional de Rio do Sul. Relatório Interno, 2001.}

FERREIRA, D. A. C.; DIAS, H. C. T. Situação atual da mata ciliar do ribeirão São Bartolomeu em Viçosa, MG. Revista Árvore, v.28, n.4, p.617-623, 2004,

HOLANDA, F. S. R. et al. Riparian vegetation affected by bank erosion in the Lower São Francisco River, Northeastern Brazil. Revista Árvore, v.29, n.2, p.327-336. 2005.

KOVACIC, D. A. et al. Effectiveness of constructed wetlands in reducing nitrogen and phosphorus export from agricultural tile drainage. Journal of Environmental Quality, v.29, n.4, p.1262-1274, 2000.
LEE, K. H.; ISENHART, T. M.; SCHULTZ, R. C. Sediment and nutrient removal in an established multi-species riparian buffer. J. Soil Water Conserv., v.58, n.1, p.1-8, 2003.

LOWRANCE, R.; DABNEY, S.; SCHULTZ, R. Improving water and soil quality with conservation buffers. J. Soil Water Conserv. v.57, n.1, p.37-43, 2002.

MAYER, P. M.; REYNOLDS JR., S. K.; CANFIELD, T. J. Riparian buffer width, vegetative cover, and nitrogen removal effectiveness: a review of current science and regulations. EPA/600/R-05/ 118, 2005. 40p.

NORDSTROM, K. F.; HOTTA, S. Wind erosion from cropland in the USA: a review of problems, solutions and prospects. Geoderma, v.121, n.1, p.157-167, 2004.

OCAMPO, C. J.; SIVAPALAN, M.; OLDHAM, C. E. Field exploration of coupled hydrological and biogeochemical catchment responses and a unifying perceptual model. Adv. Water Res., v.29, n.1, p.161-180, 2006.

PRIMAK, R. B.; RODRIGUES, E. Biologia da conservação. Londrina: Planta, 2001. 327p.

STONE, K. C. et al. Stream nitrogen changes in an eastern Coastal Plain watershed. Journal of Soil and Water Conservation, v.59, n.2, p.66-72, 2004.

TEIXEIRA, L. P. Caracterização hidrológica dos solos da bacia experimental do Ribeirão Concórdia, Lontras, SC. 2008. 112f. Dissertação (Mestrado em Engenharia Ambiental) Universidade Regional de Blumenau, Blumenau, 2008. 112p.

VIBRANS, A. C. A cobertura florestal da bacia do Rio Itajaí - elementos para uma análise histórica. 2003. $240 \mathrm{f}$. Tese (Doutorado em Geografia) -

Universidade Federal de Santa Catarina, Florianópolis, 2003. 
